Maciej Etel

\title{
NOWY PRZEDSIĘBIORCA W USTAWIE Z 6 MARCA 2018 R. PRAWO PRZEDSIĘBIORCÓW
}

\author{
NEW ENTREPRENEUR IN THE ACT OF 6 MARCH 2018 - \\ LAW OF ENTREPRENEURS
}

\begin{abstract}
Streszczenie: Ustawa z 6 marca 2018 r. Prawo przedsiębiorców modyfikuje, względem obowiązujących na gruncie ustawy z 2 lipca 2004 r. o swobodzie działalności gospodarczej, brzmienie definicji legalnych pojęć „przedsiębiorca” oraz „działalność gospodarcza” i w ten sposób tworzoną nową koncepcję identyfikacyjną. Niniejsze opracowanie wskazuje na potrzebę tych zmian, przedstawia znaczenie terminu „przedsiębiorca” oparte na art. 4 ust. 1 i art. 3 u.PP, w tym także kategorię tzw. działalności nieewidencjonowanej, o której mowa $w$ art. 5 tego aktu. Ukierunkowane jest przede wszystkim na ukazanie odmienności względem definicji obowiązujących na gruncie u.SDG oraz zasygnalizowanie trudności interpretacyjnych oraz problemów praktycznych, które mogą one powodować.
\end{abstract}

Słowa kluczowe: przedsiębiorca, działalność gospodarcza, identyfikacja, problemy, prawo przedsiębiorców

Received: 07.2018

\begin{abstract}
The new sense of the term entrepreneur (in force from 30 April 2018) is specified in the form of a legal definition formed in Article 4 of the Act of 6 March 2018 - Law of Entrepreneurs. In accordance with this regulation, an entrepreneur is a natural person, legal person and organisational entity not being a legal person, to whom a separate law grants legal capacity, and who performs an entrepreneurial activity. This article is aimed at pointing at key differences in the identification of entrepreneur between the new and the former definition (which was formed in Article 4 of the Act of 2 July 2004 on Freedom of Entrepreneurial Activity). It also indicates the consequences, including the difficulties, that this reform may cause in practice.
\end{abstract}

Key words: entrepreneur, entrepreneurial activity, legal definition, identification problems, law of entrepreneurs.

Accepted: 09.2018

\footnotetext{
"Doktor nauk prawnych, adiunkt w Katedrze Prawa Gospodarczego Publicznego na Wydziale Prawa Uniwersytetu w Białymstoku
} 


\section{Wprowadzenie}

Ustawa z 6 marca 2018 r. Prawo przedsiębiorców ${ }^{1}$ weszła w życie 30 kwietnia $2018 r^{2}$. Akt ten stanowi fundament reform³ ${ }^{3}$ których głównym założeniem jest poszerzenie wolności gospodarczej oraz stworzenie nowych zasad podejmowania, wykonywania i zakończenia działalności gospodarczej w Polsce. W założeniu twórców nastąpi to dzięki wyeliminowaniu niedoskonałości, wypełnieniu braków i luk, uporządkowaniu i uproszczeniu prawa kształtującego sytuację prawną przedsiębiorcy [Uzasadnienie 2018, 1-5] - poprzez przygotowanie oraz wdrożenie nowej „konstytucji działalności gospodarczej" ${ }^{\prime 4}$.

Zmiany objęły również identyfikację przedsiębiorcy. W u.PP zmodyfikowano, względem obowiązujących na gruncie u.SDG, brzmienie definicji legalnych pojęć przedsiębiorca oraz działalność gospodarcza i w ten sposób stworzono nowe narzędzia i nową koncepcję identyfikacyjną.

Niniejsze opracowanie wskazuje na potrzebę tych zmian, przedstawia znaczenie terminu „przedsiębiorca” oparte na art. 4 ust. 1 i art. 3 u.PP, w tym także kategorię tzw. działalności nieewidencjonowanej, o której mowa

\footnotetext{
${ }^{1}$ Ustawa z 6 marca 2018 r. Prawo przedsiębiorców (Dz. U. z 2018 r., poz. 646) - dalej u.PP.

${ }^{2}$ W konsekwencji z 30 kwietnia 2018 r. moc obowiązującą utraciły przepisy ustawy z 2 lipca 2004 r. o swobodzie działalności gospodarczej (tekst jedn. Dz. U. z 2017 r., poz. 2168 ze zm.) dalej u.SDG. Zob. art. 1 ust. 1 i art. 192 ustawy z 6 marca 2018 r. Przepisy wprowadzające ustawę - Prawo przedsiębiorców oraz inne ustawy dotyczące działalności gospodarczej (Dz. U. z 2018 r., poz. 650).

3 Reforma obejmuje wprowadzenie 4 głównych ustaw tj.: ustawa z 6 marca 2018 r. Prawo przedsiębiorców (Dz. U. z 2018 r., poz. 646), ustawa z 6 marca 2018 r. o Centralnej Ewidencji i Informacji o Działalności Gospodarczej i Punkcie Informacji dla Przedsiębiorcy (Dz. U. z 2018 r., poz. 647), ustawa z 6 marca 2018 r. o Rzeczniku Małych i Średnich Przedsiębiorców (Dz. U. z 2018 r., poz. 648), ustawa z 6 marca 2018 r. o zasadach uczestnictwa przedsiębiorców zagranicznych i innych osób zagranicznych w obrocie gospodarczym na terytorium Rzeczypospolitej Polskiej (Dz. U. z 2018 r., poz. 649), a także zmiany w kilkudziesięciu ustawach odrębnych - zob. art. 2-190 Przepisów wprowadzających.

${ }^{4}$ U.PP kontynuuje ugruntowaną $w$ tradycji prawa polskiego metodę regulowania fundamentalnych zasad podejmowania, wykonywania i zakończenia działalności gospodarczej aktem o znaczeniu nadrzędnym tj. swoistą „konstytucją działalności gospodarczej” [Zdyb, Kruk, Lubeńczuk (red.) 2018, 53-58].
} 
w art. 5 tego aktu. Ukierunkowane jest przede wszystkim na ukazanie odmienności względem definicji obowiązujących na gruncie u.SDG oraz zasygnalizowanie trudności interpretacyjnych oraz problemów praktycznych, które mogą one powodować ${ }^{5}$.

Celem publikacji jest również ustalenie, czy koncepcja identyfikacyjna przedsiębiorcy przyjęta w u.PP odpowiada rzeczywistym potrzebom i rozwiązuje problemy charakteryzujące prawo polskie? Odpowiedź na tak postawione pytanie umożliwi ocenę reform oraz sformułowanie postulatów de lege lata i de lege ferenda.

\section{Potrzeba reform}

Zainteresowanie ustawodawcy przedsiębiorcą nie powinno zaskakiwać. Z oczywistych względów nie może on pozostawać wobec przedsiębiorcy obojętny ${ }^{6}$, lecz powinien uregulować obowiązki i uprawnienia przedsiębiorców względem państwa, a także wobec innych przedsiębiorców, konsumentów, pracowników i wielu innych jeszcze podmiotów, z podmiotami międzynarodowymi włącznie [Kosikowski 2010, 117 i n., Grabowski, Kieres, WalaszekPyzioł (red) 2013, 753 i n., Grabowski, Kieres, Walaszek-Pyzioł (red.), 2013, 779 i n., Banasiński, Glibowski, Gronkiewicz-Waltz, Jaroszyński, Kaszubski, Wierzbowski 2009, 158 i n., Strzyczkowski 2009, 155 i n., Zdyb 1997, 387 i n.].

Niestety stan prawa polskiego w zakresie kształtującym zasady funkcjonowania przedsiębiorców nie jest prawidłowy. Różnego rodzaju mankamenty widoczne są w wielu sferach i obejmują wiele zróżnicowanych kwestii [Kosikowski, Etel 2014, 13 i n.].

Zarzut ten dotyczy również koncepcji przedsiębiorcy. Warto bowiem zauważyć, że identyfikacja przedsiębiorcy jest zadaniem wymagającym, a niekiedy wręcz niemożliwym. Źródłem problemów są przede wszystkim:

\footnotetext{
${ }^{5}$ Z tego względu opracowanie nie zawiera kompleksowej i rozbudowanej analizy poszczególnych cech relewantnych decydujących o przedsiębiorcy i działalności gospodarczej. W tym zakresie stosuje odesłania do rozbudowanego dorobku nauki i judykatury oraz korzysta z innych publikacji Autora.

${ }^{6} \mathrm{Na}$ istotną rolę przedsiębiorców dla Państwa wyraźnie wskazują twórcy reformy [Uzasadnienie 2018, 9-10].
} 
1) cechy relewantne, na których opiera się znaczenie pojęcia (w szczególności charakteryzujące działalność gospodarczą) sprawiają istotne trudności interpretacyjne, nie są wystarczająco jednoznaczne, a ich znaczenie $w$ dalszym ciągu jest szeroko dyskutowane [Etel 2012, 171273];

2) normatywne wyłączenia podmiotowe i przedmiotowe, w konsekwencji których przedsiębiorcą można nie być pomimo wykonywania działalności gospodarczej albo ze względu na to, że aktywność wypełniająca kryteria działalności gospodarczej została ex lege wykluczona z tej kategorii [Etel 2012, 192-200];

3) ukonstytuowanie w prawie pewnych szczególnych (kwalifikowanych) kategorii przedsiębiorców i działalności gospodarczej;

4) niezasadne traktowanie niektórych podmiotów na równi z przedsiębiorcami [Etel 2012, 246-257], a także luki w tym zakresie [Etel 2012, 232-235];

5) wadliwie skonstruowany i nieprawidłowo funkcjonujący system legalizacji działalności gospodarczej, który niejednokrotnie kwalifikuje jako przedsiębiorców podmioty nie wykonujące działalności gospodarczej, albo odwrotnie, statusu tego nie uzyskują podmioty prowadzące we własnym imieniu działalność gospodarczą [Etel 2012, 257-264];

6) równoległe funkcjonowanie wielu definicji nadających tym terminom znaczenie odmienne od wskazanego w „konstytucji działalności gospodarczej" [Etel 2012, 274-354, Kosikowski, Etel 2014, 133-137];

7) niespójność z ukształtowanym w dorobku Unii Europejskiej znaczeniem i sposobem identyfikacji przedsiębiorcy [Etel 2012, 98-130].

Przedstawione wyliczenie z pewnością nie wyczerpuje ułomności koncepcji identyfikacyjnej przedsiębiorcy funkcjonującej w okresie obowiązywania u.SDG. Jednakże już na tej podstawie można twierdzić, że stan ten nie był prawidłowy i wymagał poprawy, a tym samym działania prawodawcze były uzasadnione i oczekiwane.

\footnotetext{
${ }^{7}$ O ile dywersyfikacja (również klasyfikacja) nie stanowi problemu i nie powinna być odczytywana za źródło trudności, to jednak określanie szczególnych kategorii przedsiębiorców i działalności gospodarczej terminami takimi jak „rzemieślnik” bądź „usługodawca” lub „gospodarka komunalna" może utrudniać identyfikację przedsiębiorcy i działalności gospodarczej.
} 
Reformy w tym zakresie są ważne, niezbędne i konieczne. Znaczenie pojęć „przedsiębiorca” i „działalność gospodarcza” określone w „konstytucji działalności gospodarczej" ma bowiem wymiar definicji systemowych, tj. precyzujących znaczenie tych pojęć na potrzeby całego systemu prawa krajowego [Katner 2007, 42, Katner 2003, 9; Zdyb 2000, 29; Kosikowski, 2000, 5-6, Walaszek-Pyzioł 1999, 2, Strzyczkowski 1999, 2; Szydło 2002, 79].

\section{Przedsiębiorca}

Obowiązującą od 30 kwietnia 2018 r. definicję legalną terminu „przedsiębiorca" zawiera art. 4 ust. 1 u.PP ${ }^{8}$. Zgodnie z tym przepisem przedsiębiorcą jest osoba fizyczna, osoba prawna lub jednostka organizacyjna niebędąca osobą prawną, której odrębna ustawa przyznaje zdolność prawną, wykonująca działalność gospodarczą ${ }^{9}$.

Konstrukcję definicji oparto na dwóch kryteriach [Banasiński, Glibowski, Gronkiewicz-Waltz, Jaroszyński, Kaszubski, Wierzbowski 2009, 216]:

1) podmiotowym - wskazującym na kategorie podmiotów, które mogą być uznane za przedsiębiorców, czyli osoby fizyczne, osoby prawne lub jednostki organizacyjne niebędące osobami prawnymi, którym odrębna ustawa przyznaje zdolność prawną;

2) przedmiotowym - charakteryzującym aktywność przedsiębiorcy, czyli działalność gospodarczą w rozumieniu art. 3 u.PP.

Oczywiście dla identyfikacji podmiotu jako przedsiębiorcy (w rozumieniu art. 4 ust. 1 u.PP) niezbędne jest ich kumulatywne wypełnienie, zaś brak któregokolwiek wyklucza taką kwalifikację.

Porównując wyżej przytoczoną definicję do znaczenia sformułowanego w uchylonym art. 4 ust. 1 u.SDG, nietrudno zauważyć dwie istotne zmiany.

\footnotetext{
${ }^{8}$ W myśl uchylonego art. 4 ust. 1 u.SDG przedsiębiorcą w rozumieniu ustawy był osoba fizyczna, osoba prawna i jednostka organizacyjna niebędąca osobą prawną, której odrębna ustawa przyznaje zdolność prawną - wykonująca we własnym imieniu działalność gospodarczą.

${ }^{9}$ Zgodnie z art. 4 ust. 2 u.PP przedsiębiorcami są także wspólnicy spółki cywilnej w zakresie wykonywanej przez nich działalności gospodarczej.
} 
Po pierwsze, w obowiązującej definicji przedsiębiorcy brak wyrażenia „w rozumieniu ustawy" istniejącego w uchylonym art. 4 ust. 1 u.SDG. Dokonana korekta była niezbędna i zasługuje na aprobatę. Wskazanie jakoby definicja przedsiębiorcy z art. 4 ust. 1 u.SDG powstała na potrzeby tylko tego aktu prawnego było błędem przeczącym jej istocie i celom definiowania - jak zostało to wyżej wskazane definicje przedsiębiorcy i działalności gospodarczej w u.SDG powstały w charakterze definicji systemowych.

Po drugie, w obowiązującej definicji przedsiębiorcy brak zastrzeżenia funkcjonalnego, w myśl którego przedsiębiorcą jest tylko taka osoba fizyczna, osoba prawna i jednostka organizacyjna nieposiadająca osobowości prawnej uposażona w zdolność prawną przez inną ustawę, która działalność gospodarczą wykonuje „we własnym imieniu”.

Zastrzeżenie to stanowiło podstawowy element definicji legalnej przedsiębiorcy [NSA 2007]. Podkreślało bowiem ponoszenie przez podmiot ryzyka gospodarczego, tj. odpowiedzialności za podejmowane w ramach działalności decyzje i ich konsekwencje, w szczególności w postaci wyników finansowych i zobowiązań prywatno- i publicznoprawnych. Tym samym pozwalało wykluczyć z grona przedsiębiorców podmioty niewykonujące działalności "we własnym imieniu”, nawet gdy ich aktywność wypełniała cechy działalności gospodarczej - dotyczyło to pracowników (działających w imieniu i na rzecz pracodawcy), pełnomocników (prokurentów) organów osób prawnych, organów spółek osobowych prawa handlowego, wspólników spółek osobowych i kapitałowych prawa handlowego, syndyków i zarządców masy upadłościowej-działających w imieniu i na rachunek innego podmiotu m.in. pracodawcy, osoby prawnej, jednostki organizacyjnej nieposiadającej osobowości prawnej uposażonej w zdolność prawną przez inną ustawę [Kosikowski 2013, 54-55, Banasiński, Glibowski, Gronkiewicz-Waltz, Jaroszyński, Kaszubski, Wierzbowski 2009, 228-229; Powałowski (red.) 2007, 48, Szydło 2005, 89-90].

Należy jednak podkreślić, że w nowej koncepcji przedsiębiorcy zastrzeżenie funkcjonalne nie zostało pominięte. Wprost na wykonywanie działalności „we własnym imieniu” wskazuje bowiem art. 3 u.PP, zawierający definicję legalną pojęcia „działalność gospodarcza”. Wydaje się zatem, że zmiana nie wpłynęła na sens, istotę i treść tego kryterium, gdyż prowadzi ono do tożsamych ustaleń, tj. wyklucza z kategorii przedsiębiorców podmioty 
niewykonujące działalności „we własnym imieniu”, nawet gdy ich aktywność wypełniała cechy działalności gospodarczej. Jednak mimo wszystko przeistoczenie podstawowej przesłanki identyfikującej przedsiębiorcę na rzecz cechy relewantnej działalności gospodarczej jest zaskakujące i nie w pełni zrozumiałe $^{10}$.

\section{Działalność gospodarcza}

Kluczowa dla identyfikacji przedsiębiorcy pozostaje kwalifikacja jego aktywności jako działalności gospodarczej. Definicję legalną tego terminu formułuje art. 3 u.PP. Zgodnie z tym przepisem działalnością gospodarczą jest zorganizowana działalność zarobkowa, wykonywana we własnym imieniu i w sposób ciągły.

Przytoczona definicja niezmiennie kształtuje znaczenie działalności gospodarczej poprzez wskazanie na cechy relewantne, odróżniające ją od innych rodzajów i form aktywności. Właściwa pozostaje również zasada, w myśl której aktywność odpowiadająca łącznie wszystkim przesłankom jest działalnością gospodarczą i w ten sposób powinna być identyfikowana ${ }^{11}$.

Obowiązująca od 30 kwietnia 2018 r. definicja różni się jednak od funkcjonującej na mocy uchylonego art. 2 u.SDG ${ }^{12}$. Zmianie uległ bowiem katalog kryteriów stanowiących o identyfikacji działalności gospodarczej.

Obecnie są to następujące cechy relewantne:

1) zarobkowy cel,

2) organizacja,

3) wykonywanie we własnym imieniu,

4) ciągłość.

Nietrudno zauważyć, że kryteria wyrażone w art. 3 u.PP współtworzyły koncepcję przedsiębiorcy opartą na art. 2 i art. 4 ust. 1 u.SDG. Właściwy za-

\footnotetext{
${ }^{10}$ Niestety twórcy reform nie wyjaśniają przyczyn i celów tej zmiany.

${ }^{11}$ Ten sposób definiowania działalności gospodarczej wpisany jest w tradycję prawa polskiego [Etel 2012, 143-170].

${ }^{12}$ W myśl uchylonego art. 2 u.SDG działalnością gospodarczą była zarobkowa działalność wytwórcza, budowlana, handlowa, usługowa oraz poszukiwanie, rozpoznawanie i wydobywanie kopalin ze złóż, a także działalność zawodowa, wykonywana w sposób zorganizowany i ciągły.
} 
tem przy ich interpretacji i stosowaniu pozostaje dotychczasowy dorobek oraz zdobyte doświadczenia. Niewątpliwie każda z zawartych w art. 3 u.PP cech działalności gospodarczej posiada już wypracowaną w nauce i judykaturze istotę, treść i sposoby interpretacji ${ }^{13}$, co jednak nie oznacza, że są precyzyjne i jednoznaczne, a ich praktyczne zastosowanie nie sprawia już trudności.

Pozytywną zmianą w definiowaniu działalności gospodarczej jest brak kryterium kwalifikacji ekonomicznej. Zawarte w art. 2 u.SDG wyliczenie, w myśl którego „działalnością gospodarczą była działalność wytwórcza, budowlana, handlowa, usługowa oraz poszukiwanie, rozpoznawanie i wydobywanie kopalin ze złóż" okazało się zbyt ogólne i generalne. Składające się nań potencjalne płaszczyzny działalności gospodarczej były nieostre i w praktyce przenikały się wzajemnie. Brak precyzji powodował, że każdą aktywność można było kwalifikować jako co najmniej jedną z wyliczonych. W rezultacie kryterium to nie odgrywało istotnej roli przy identyfikacji działalności gospodarczej, a jego wyeliminowanie wpisuje się w założenia twórców reformy, gdyż czyni definicję działalności gospodarczej z art. 3 u.PP bardziej czytelną i przystępną w odbiorze ${ }^{14}$.

Akcentując kolejne odmienności względem u.SDG, warto zauważyć, że w definicji działalności gospodarczej z art. 3 u.PP wyraźnie oddzielono kryteria organizacji i ciągłości ${ }^{15}$.

Pomysł ten wzbudza pewne wątpliwości. W szczególności dotyczą one ciągłości, która ze względu na dużą liczbę wyjątków jest najbardziej względną, nieprecyzyjną i trudną w ocenie cechą działalności gospodarczej [Kosikowski 2013, 32-34; Katner 2003, 23-24] ${ }^{16}$.

\footnotetext{
${ }^{13}$ Do której odwołują się twórcy reformy [Uzasadnienie 2018, 19-21].

${ }^{14} \mathrm{~W}$ analogiczny sposób zmianę uzasadniają twórcy reformy [Uzasadnienie 2018, 19].

${ }^{15} \mathrm{Na}$ dywersyfikację tych organizacji i ciągłości wskazują twórcy reform w uzasadnieniu [Uzasadnienie 2018, 19-21].

16 „Względnie stałego zamiaru” nie wyklucza bowiem wykonywanie działalności wyłącznie sezonowo, albo do czasu osiągnięcia założonego przez podmiot celu. Co więcej nawet czynność wykonana jednorazowo może zostać uznana za działalność gospodarczą. Wyjątku od „regularności i powtarzalności” można dopatrywać się również w instytucji zawieszenia działalności gospodarczej uregulowanej w art. 22-25 u.PP, w przypadku której podmiot czasowo
} 
Jednocześnie nie można kwestionować tego, że „regularność i powtarzalność" jest cechą właściwą i powinna mieć wpływ na identyfikację działalności gospodarczej. Istotne jest jednak, aby nie postrzegać jej odrębnie i samoistnie, lecz traktować jako niezbędną przesłankę subsydiarną, która dopełniając formalną i materialną organizację, oddaje istotę sposobu wykonywania działalności gospodarczej [Etel 2012, 187-192].

Doświadczenia z okresu obowiązywania u.SDG uzasadniają twierdzenie, że organizacja i ciągłość muszą być postrzegane jako cechy komplementarne, uzupełniające się wzajemnie i łącznie współtworzące jedno kryterium sposobu wykonywania działalności gospodarczej. Tylko wtedy zrealizują przypisaną im rolę tzn. wyeliminują z kategorii gospodarczej aktywność, która ma charakter okazjonalny, przypadkowy i nie jest zorganizowana, nawet gdy przyniesie podmiotowi wykonującemu zysk, co dotyczy m.in. czynności wykonywanych w ramach pomocy sąsiedzkiej lub koleżeńskiej bądź w ramach tzw. czynności grzecznościowych - nawet jeżeli ich wykonywanie jest odpłatne [Kosikowski 2013, 31-34, Katner 2003, 22]. W przeciwnym razie, tj. interpretowane niezależnie $\mathrm{i}$ indywidualnie jak sugeruje to aktualna konstrukcja art. 3 u.PP, mogą okazać się źródłem wielu niejasności i kontrowersji.

Dyskusyjna jest również rezygnacja z zawodowego charakteru działalności gospodarczej ${ }^{17}$. Kryterium to było bowiem ukierunkowane na rozstrzygnięcie problemu identyfikacji przedstawicieli tzw. wolnych zawodów jako przedsiębiorców.

Trzeba pamiętać, że akcentując różnice pomiędzy wykonywaniem wolnego zawodu, a „typową” działalnością gospodarczą ${ }^{18}$, a także wykorzystując podmiotowe i przedmiotowe wyłączenia normatywne, podnoszono, że przedstawiciele tych profesji nie wykonują działalności gospodarczej, lecz

wstrzymuje się w wykonywaniu działalności, a zatem faktycznie jej nie prowadzi, lecz działalność w okresie zawieszenia niezmiennie traktowana jest jako gospodarcza, a sam podmiot jako przedsiębiorca [SN 2008, SN 2007, WSA w Warszawie 2009, SN 2003, SN 1996].

${ }^{17}$ Zgodnie z art. 2 u.SDG działalnością gospodarczą była także działalność zawodowa.

${ }^{18}$ Są to m.in. regulowany charakter, osobisty udział, kwalifikowane wykształcenie, ustalone sposoby i formy organizacyjne wykonywania zawodu, niezależność zawodowa, etos zawodowy, wynagrodzenie, tajemnica zawodowa, samorządność korporacyjna i odpowiedzialność prawna [Jacyszyn 2004, 38-107]. 
wyłącznie działalność zawodową. Podkreślano jednocześnie, że działalność gospodarcza i zawodowa nie są tożsame, lecz zdecydowanie różne, na co wskazuje wprost art. $43^{1} \mathrm{KC}^{19}$. Na tej podstawie twierdzono, że skoro przedstawiciele wolnych zawodów nie wykonują działalności gospodarczej (lecz działalność zawodową, o której mowa w art. $43^{1} \mathrm{KC}$ ), to nie należy ich postrzegać jako przedsiębiorców, a tym bardziej wymagać realizacji obowiązków przypisanych przedsiębiorcom i działalności gospodarczej. Te argumenty i proponowana wykładnia obowiązujących wówczas przepisów były szeroko dyskutowane i wywołały wiele polemik [Etel 2012, 183-187].

W konsekwencji zamieszczenia w treści definicji legalnej działalności gospodarczej z art. 2 u.SDG sformułowania „a także działalność zawodowa” kwestia kwalifikacji przedstawicieli wolnych zawodów jako przedsiębiorców została rozstrzygnięta a problem rozwiązany: są oni przedsiębiorcami, o ile wykonywana przez nich (we własnym imieniu) działalność zawodowa charakteryzuje się cechami działalności gospodarczej (do 30 kwietnia 2018 r. wskazanymi w art. 2 u.SDG) [Kosikowski 2003, 35, Powałowski (red.) 2007, 25-26].

Zdaniem twórców reform brak kryterium zawodowego charakteru w obowiązującej definicji wynika z przekonania, że wskazany wyżej problem ma wymiar wyłącznie historyczny, a obecnie każdą działalność zawodową można uznać za działalność gospodarczą, jeśli ma charakter zarobkowy, zorganizowany i ciągły, tak więc w treści art. 3 u.PP nie ma potrzeby wskazywać, że pojęcie działalności gospodarczej obejmuje również działalność zawodową [Uzasadnienie 2018, 20].

Niewykluczone jednak, że brak ten może sprowokować ponowną dyskusję nad zasadnością traktowania działalności zawodowej jako działalności gospodarczej. Jest to o tyle prawdopodobne, że istotna część wykorzystywanych w przeszłości argumentów pozostaje aktualna: niezmiennie działalność wolnych zawodów charakteryzuje się cechami własnymi odróżniającymi ją od „typowej” działalności gospodarczej, a art. $43^{1}$ KC wyraźnie dywersyfikuje działalność gospodarczą od zawodowej.

\footnotetext{
${ }^{19}$ Zgodnie z art. $43^{1} \mathrm{KC}$ przedsiębiorcą jest osoba fizyczna, osoba prawna i jednostka organizacyjna, o której mowa $w$ art. $33^{1} \S 1$, prowadząca we własnym imieniu działalność gospodarczą lub zawodową.
} 


\section{Działalność nieewidencjonowana}

Omawiając koncepcję przedsiębiorcy należy również zwrócić uwagę na nowe, dotychczas nieznane w prawie polskim, wyłączenie z kategorii działalności gospodarczej.

Na mocy art. 5 ust. 1 u.PP za działalność gospodarczą nie jest bowiem uznawana działalność nieewidencjonowana, tj. wykonywana przez osobę fizyczną, której przychód należny ${ }^{20} z$ tej działalności nie przekracza w żadnym miesiącu 50\% kwoty minimalnego wynagrodzenia za pracę ${ }^{21}$ i która w okresie ostatnich 60 miesięcy nie wykonywała działalności gospodarczej ${ }^{22}$.

Działalność nieewidencjonowana identyfikowana jest poprzez trzy kryteria:

1) podmiotowe - działalność ta jest wykonywana wyłącznie przez osobę fizyczną;

2) przychodowe - przychód należny z tej działalności nie przekracza w żadnym miesiącu 50\% kwoty minimalnego wynagrodzenia za pracę (jeżeli przychód należny z działalności przekroczy w danym miesiącu przyjętą wysokość to działalność ta staje się działalnością gospodarczą, począwszy od dnia, w którym nastąpiło przekroczenie wysokości [art. 5 ust. 3 u.PP], zaś osoba wykonująca zobligowana jest wystąpić z wnioskiem o wpis do Centralnej Ewidencji i Informacji o Działalności Gospodarczej w terminie 7 dni od dnia, w którym nastąpiło przekroczenie wysokości [art. 5 ust. 4 u.PP]) ${ }^{23}$;

\footnotetext{
${ }^{20}$ Zgodnie z art. 5 ust. 6 u.PPprzez przychód należny rozumie się kwoty należne, choćby nie zostały faktycznie otrzymane, po wyłączeniu wartości zwróconych towarów, udzielonych bonifikat i skont.

${ }^{21}$ O którym mowa w ustawie z 10 października 2002 r. o minimalnym wynagrodzeniu za pracę (tekst jedn. Dz. U. z 2017 r., poz. 847 ze zm.).

22 Ponadto, na podstawie art. 195 ustawy z 6 marca 2018 r. Przepisy wprowadzające, przepisy o działalności nieewidencjonowanej stosuje się również do działalności wykonywanej przez osoby, które w okresie 1 roku przed dniem wejścia w życie ustawy nie były wpisane do CEIDG lub które zostały wykreślone z CEIDG więcej niż 1 rok przed dniem wejścia w życie ustawy, nawet jeżeli w okresie ostatnich 60 miesięcy przed dniem wejścia w życie ustawy wykonywały działalność gospodarczą.

${ }^{23}$ Warto również dodać, że na mocy art. 5 ust 2 u.PPosoba wykonująca działalność nieewidencjonowaną może złożyć wniosek o wpis do Centralnej Ewidencji i Informacji o Działalności
} 
3) formalne - a) niewykonywanie działalności gospodarczej przez okres ostatnich 60 miesięcy, b) działalność nie jest wykonywana w formie spółki cywilnej [art. 5 ust. 5 u.PP], c) działalność nie wymaga uzyskania koncesji, zezwolenia bądź wpisu w rejestrze działalności regulowanej [art. 44 ust. 3 u.PP].

Intencje wprowadzenia działalności nieewidencjonowanej i jej wyłączenie z kategorii działalności gospodarczej wydają się zrozumiałe i racjonalne. Można bowiem założyć, że ustawodawca ze względu na niewielką skalę działalności prowadzonej jednoosobowo przez osobę fizyczną chce uwolnić ją od obowiązków przypisanych działalności gospodarczej i przedsiębiorcy, które w tym przypadku traktuje jako nieproporcjonalne i zbyt uciążliwe.

Trzeba jednak podkreślić, że konstrukcja ta pozostawia wątpliwości, które dotyczą zarówno statusu podmiotu wykonującego działalność nieewidencjonowaną, jak również zakresu oraz skutków wyłączenia na gruncie u.PP i innych aktów prawnych.

Analizując art. 5 u.PP, trudno bowiem stwierdzić ${ }^{24}$ : a) czy działalność nieewidencjonowana jest działalnością gospodarczą w rozumieniu przepisów innych ustaw; b) czy osoba fizyczna wykonująca działalność nieewidencjonowaną jest przedsiębiorcą w rozumieniu u.PP; c) czy osoba fizyczna wykonująca działalność nieewidencjonowaną jest przedsiębiorcą $w$ rozumieniu przepisów innych ustaw; d) czy działalność nieewidencjonowana, a w konsekwencji podmiot wykonujący jest zwolniony od wszelkich obowiązków, które obowiązujące prawo kieruje do działalności gospodarczej i przedsiębiorców, czy też wyłącznie z obowiązków określonych w u.PP; e) czy do działalności nieewidencjonowanej i podmiotu ją wykonującego stosuje się ograniczenia kontroli działalności gospodarczej oznaczone w art. u.PP; f) czy osoba fizycz-

Gospodarczej, a działalność ta staje się działalnością gospodarczą z dniem określonym we wniosku.

${ }^{24}$ W uzasadnieniu stwierdzono, iż konsekwencją wyłączenia działalności nieewidencjonowanej z kategorii działalności gospodarczej jest to, że podmiot ją wykonujący nie jest przedsiębiorcą w rozumieniu u.PP. Natomiast może on być przedsiębiorcą w rozumieniu przepisów KC zobowiązanym do przestrzegania przepisów KC adresowanych do przedsiębiorców, w tym przepisów wiążących przedsiębiorców w relacjach z konsumentami [Uzasadnienie 2018, 2122]. 
na wykonująca działalność nieewidencjonowaną może korzystać z uprawnień przypisanych przedsiębiorcy?

\section{Wnioski}

Nową koncepcję przedsiębiorcy trudno ocenić jednoznacznie.

W porównaniu do identyfikacji opartej na art. 4 ust. 1 i art. 2 u.SDG wprowadzono zmiany korzystne. Brak sformułowania „w rozumieniu ustawy" w definicji przedsiębiorcy oraz kryterium kwalifikacji ekonomicznej w definicji działalności gospodarczej przynajmniej częściowo eliminują problem właściwości i zastosowania znaczenia tych pojęć określonego w „konstytucji działalności gospodarczej", a definicje czynią bardziej przystępnymi w odbiorze. W tym wymiarze nową koncepcję przedsiębiorcy należy ocenić pozytywnie.

Zdecydowano się także na kroki dyskusyjne. Można bowiem polemizować z zasadnością przeniesienia zastrzeżenia funkcjonalnego do definicji legalnej działalności gospodarczej, wyraźnego rozdzielenia organizacji i ciągłości charakteryzujących działalność gospodarczą, rezygnacją z kryterium zawodowego charakteru, a także wprowadzeniem działalności nieewidencjonowanej i jej wyłączeniem z kategorii działalności gospodarczej. Konsekwencje tych działań będzie można ocenić dopiero po pewnym czasie.

Jednocześnie warto zwrócić uwagę, że zmiany odnoszą się wyłącznie do narzędzi służących identyfikacji, czyli do brzmienia definicji legalnych określonych w art. 4 ust. 1 oraz art. 3 u.PP, i w zasadzie sprowadzają się do korekty kryteriów decydujących o przedsiębiorcy i działalności gospodarczej. Oczywiście działania w tym zakresie były uzasadnione. Tym niemniej trzeba pamiętać, że głównym źródłem problemów i trudności przy identyfikacji nie jest u.PP (i nie była u.SDG), lecz system prawa, tj. przepisy ustaw odrębnych.

Jest to ważne spostrzeżenie. Pozwala bowiem twierdzić, że podjęte działania są niewystarczające. Nie odpowiadają wskazywanym w nauce i judykaturze potrzebom, pomijają kluczowe kwestie i nie rozwiązują najważniejszych problemów charakteryzujących tę część krajowego porządku prawnego.

W rezultacie gruntowne, kompleksowe reformy wykraczające ponad u.PP są wciąż niezbędne i konieczne. Niestety aktualna pozostaje również 
teza, że pomimo niemałej ewolucji znaczenia pojęcia „przedsiębiorcy” nie można uznać za ostatecznie przesądzone i zamknięte [Jacyszyn 2003, 51, Szydło 2002, 105].

\section{Bibliografia}

Banasiński C., Glibowski K., Gronkiewicz-Waltz H., Jaroszyński K., Kaszubski R., Wierzbowski M., Prawo gospodarcze. Zagadnienia administracyjnoprawne, Warszawa 2009

Grabowski J., Kieres L., Walaszek-Pyzioł A. (red.), Publiczne prawo gospodarcze. Tom 8a, Warszawa 2013

Grabowski J., Kieres L., Walaszek-Pyzioł A. (red.), Publiczne prawo gospodarcze. Tom 8b, Warszawa 2013

Jacyszyn J., Wykonywanie wolnych zawodów w Polsce, Warszawa 2004

Jacyszyn J., Przedsiębiorca a wolny zawód, Rejent 2003, Nr 10

Katner W.J., Prawo działalności gospodarczej. Komentarz. Orzecznictwo. Piśmiennictwo, Warszawa 2003

Katner W.J., Pojęcie przedsiębiorcy - polemika, PPH 2007, Nr 4

Kosikowski C., Publiczne prawo gospodarcze Polski i Unii Europejskiej, Warszawa 2010

Kosikowski C., Prawo działalności gospodarczej. Komentarz, Warszawa 2000

Kosikowski C., Ustawa o swobodzie działalności gospodarczej. Komentarz, Warszawa 2013

Kosikowski C., Etel M., Nowe prawo działalności gospodarczej, Białystok 2014

Powałowski A. (red.), Ustawa o swobodzie działalności gospodarczej. Komentarz, Warszawa 2007

Strzyczkowski K., Instytucje prawa działalności gospodarczej. Uwagi o projekcie ustawy Prawo działalności gospodarczej, PUG 1999, Nr 4

Strzyczkowski K., Prawo gospodarcze publiczne, Warszawa 2009

Szydło M., Pojęcie przedsiębiorcy w prawie polskim, Przegląd Sądowy 2002, Nr 7-8

Szydło M., Swoboda działalności gospodarczej, Warszawa 2005

Ustawa z 10 października 2002 r. o minimalnym wynagrodzeniu za pracę (tekst jedn. Dz. U. z 2017 r., poz. 847 ze zm.)

Ustawa z 2 lipca 2004 r. o swobodzie działalności gospodarczej (tekst jedn. Dz. U. z 2017 r., poz. 2168 ze zm.) 
Ustawa z 6 marca 2018 r. Prawo przedsiębiorców (Dz. U. z 2018 r., poz. 646)

Ustawa z 6 marca 2018 r. o Centralnej Ewidencji i Informacji o Działalności Gospodarczej i Punkcie Informacji dla Przedsiębiorcy (Dz. U. z 2018 r., poz. 647)

Ustawa z 6 marca 2018 r. o Rzeczniku Małych i Średnich Przedsiębiorców (Dz. U. z 2018 r., poz. 648)

Ustawa z 6 marca 2018 r. o zasadach uczestnictwa przedsiębiorców zagranicznych i innych osób zagranicznych w obrocie gospodarczym na terytorium Rzeczypospolitej Polskiej (Dz. U. z 2018 r., poz. 649)

Ustawa z 6 marca 2018 r. Przepisy wprowadzające ustawę - Prawo przedsiębiorców oraz inne ustawy dotyczące działalności gospodarczej (Dz. U. z 2018 r., poz. 650)

Uzasadnienie rządowego projektu ustawy - Prawo przedsiębiorców. Druk nr 2051 z 21.11.2017 r., http://www.sejm.gov.pl [data dostępu 20.5.2018]

Walaszek-Pyzioł A., Status prawny przedsiębiorcy w świetle projektu ustawy - Prawo działalności gospodarczej, PUG 1999, Nr 5

Wyrok NSA w Warszawie z 1 czerwca 2007 r., OSK 961/06, Lex Nr 354721

Wyrok SN z dnia 4 stycznia 2008 r., I UK 208/07, Lex Nr 442841

Wyrok SN z dnia 21 lutego 2007 r., I CSK 450/06, Lex Nr 274205

Postanowienie SN z 17 lipca 2003 r., II UK 111/03, OSNP 2003, Nr 17, poz. 1, Lex Nr 79921

Wyrok SN z 11 października 1996 r., III RN 4/96, OSNP 1997, Nr 10, poz. 160, Lex Nr 28627

Wyrok WSA w Warszawie z 28 stycznia 2009 r., VII SA/Wa 1374/08, Lex Nr 489317

Zdyb M., Publiczne prawo gospodarcze, Kraków-Lublin 1997

Zdyb M., Prawo działalności gospodarczej. Komentarz do ustawy z dnia 19 listopada 1999 r., Kraków 2000

Zdyb M., Kruk E., Lubeńczuk G. (red.), Dysfunkcje publicznego prawa gospodarczego, Warszawa 2018 